\title{
Conclusion
}

I started this book with the following questions: how is suffering gendered? How does gender inform both the experiences of those who victimise and those who are victimised during war/armed conflict? I promised that this would be a qualitative rather than a quantitative comparative endeavour based on the lived experiences of victims, survivors and perpetrators. My goal was to offer a critical understanding of gender essentialism within accounts of gender and the violence(s) of war/ armed conflict. By placing the lived experiences of women and girls before, during and in the aftermath of war/armed conflict along a continuum of violence, victimisation and coerced sexual activities, I sought to offer a more nuanced account of their lives. At the same time, drawing on Feminist and Visual Criminology, I offered a holistic account of women's involvement in sexualised violence and torture. To complete this story, and redress existing gaps within the literature, I examined the experiences of male victims and survivors. In order to reflect in more detail on the aims and content of the book, let us revisit and expand upon the five key messages outlined in the Introduction.

1. The GBV(s) that take place during and in the aftermath of armed conflict cannot be reduced to visible acts of interpersonal violence. They also include, and are connected to, structural violence, State crimes and institutional organisations (see Chapters 2, 3, 4 and 5).

I will unpack each of these categories in more detail below.

\section{Structural Violence}

The securitisation agenda ironically, and perhaps paradoxically, undermines its own agenda: the elimination of wartime rape and sexual violence. It does so in two main ways. First, it selectively focuses on the experiences of women and girls, thereby obscuring those of men and boys. Second, it fails to address the range of violence(s) committed during war/armed conflict, thereby overlooking the range of causal factors. By ignoring structural types of violence, as well as reproductive

Gender and the Violence(s) of War and Armed Conflict:

More Dangerous to be a Woman?, 159-171

Copyright $(\mathcal{C} 2020$ by Stacy Banwell. Published by Emerald Publishing Limited.

This work is published under the Creative Commons Attribution (CC BY 4.0) licence. Anyone may reproduce, distribute, translate and create derivative works of this work (for both commercial and non-commercial purposes), subject to full attribution to the original publication and authors. The full terms of this licence may be seen at http://creativecommons.org/ licences/by/4.0/legalcode" Knowledge Unlatched Open Access doi:10.1108/978-1-78769-115-520201009 
and genocidal violence committed against men and boys, it limits what falls under its remit of investigation/analysis.

In terms of my third example of structural violence - women's lack of access to formal employment, resulting in forced prostitution and survival sex - consider the women and girls in Iraq and Syria involved in coerced sexual activities (not to be confused with those trafficked for sexual purpose, see Chapters 3 and 4). These females occupy the following identities simultaneously: victim, survivor and actor. While force is present, in some cases so too is 'relative autonomy' (Sjoberg \& Gentry, 2008; see Chapter 3). These women are three-dimensional agents.

While security actors, activists (such as Lisa Shannon) and celebrities (such as Charlize Theron and Nicole Kidman) may have good intentions, raising awareness about the plight of victims in war-torn regions, ultimately, this work - which focuses narrowly on one aspect of wartime/conflict violence - will only assist us on a cursory level. Our efforts to combat the violence(s) of war/armed conflict are impeded by the following: our tendency to speak for and about women and girls; our focus on certain types of victims (females rather than males) and our focus on certain types of violence (rape and sexual violence) at the expense of structural violence. The ways in which western discourses often distort and universalise the experiences of oppressed women and girls in the Global South were raised in Chapter 2. This was done with reference to Spivak's insightful essay, 'Can the subaltern speak? (1988) and Mohanty's arguments about the monolithic thirdworld-woman (1988). Gendered civilising missions and the postcolonial feminist critique were also discussed in this chapter.

Rape and sexual violence are tools used by both males and females for different reasons in different contexts. As we have seen in the various case studies under review, these acts of violence can be strategic (the DRC, the 1971 Liberation War and the conflict Darfur, as well as opportunistic (the Holocaust and the sexualised violence committed at Abu Ghraib). While these are important distinctions to make, particularly for conversations about tackling such violence(s), let us not forget that these are only two examples of the violence(s) committed during war/ armed conflict. We must broaden the range of wartime/conflict violence that we examine. Throughout the book, by including examples of structural violence, I have extended what counts as violence and expanded the diagnostic framework which facilitates this broader analysis.

\section{State Crimes}

As outlined in Chapter 2, State crimes violate international and domestic laws. They are committed by representatives of the State often for economic, geopolitical and ideological reasons (Mullins \& Rothe, 2008, p. 83). In the context of this book, gender, in the form of globalisation masculinities, was also regarded as a motivating factor. I unpacked State crimes in relation to the armed conflicts in the DRC and Iraq. In both examples, these macro-level illegal actions were connected to acts of sexual gender-based violence (SGBV) committed against civilian women and girls. 
In both examples, these State crimes were/are committed against the backdrop of masculinities of postcolonialism and neoliberalism. In the case of the DRC, transnational companies engage in the illegal exportation of minerals, using the chaos of the conflict - which involves the strategic use of wartime rape and sexual violence - to achieve their economic goals. This implicates them in Statecorporate crimes. The US invaded Iraq without legal authorisation, failing to meet the legal standard of self-defence. This act of aggression has been described by criminologists as a State crime (Kramer \& Michalowski, 2005, 2011; see also Whyte, 2007). As demonstrated in Chapter 3, following the US intervention in Iraq, GBV against women and girls increased. Furthermore, following the privatisation agenda of the west, women and girls were forced into the illicit economy where they either engaged in forced prostitution or were trafficked for sexual purposes. In both armed conflicts, State crimes maintain and exacerbate the use of sexual GBV against civilian women and girls within and beyond the conflict zone. Based on this, I posit that the interpersonal violence(s) that took/take place emerge from an interpersonal-State nexus.

\section{Institutional Violence}

While the US government attempted to distance themselves from the violence(s) that took place at Abu Ghraib - referring to those involved as 'a few bad apples' the sexualised violence and torture was carried out by individuals working for the US military. As I argued in Chapter 5, while agency must be ascribed to those individuals who carried out these acts of interpersonal violence, they cannot be divorced from the wider context of the war on terror and its driving force: American exceptionalism. As a result, I posit that the interpersonal violence(s) of Abu Ghraib can be attributed to an interpersonal-institutional nexus.

\section{As both symbolic and corporeal mothers of the nation, women are at risk of reproductive and genocidal violence during war/armed conflict (Chapter 1).}

On a symbolic level, discourses of war/armed conflict construct the maternal body as a canvas upon which national, racial, ethnic and religious identities are inscribed (Cohn, 2013). Corporeally, and within 'nationalist discourses', women are the bearers of the next generation of (preferably male) fighters (Åhäll, 2017, p. 22). Perversely, in the context of the Holocaust, women's biological maternal function formed part of the Nazi genocide. In this instance, women's ability to produce future generations of Jews led to crimes of 'reproductive violence' (Grey, 2017) in the form of forced sterilisation and forced abortions. In the case of the 1971 Liberation War in Bangladesh, as representations of their nation, it is estimated that between 200,000 and 400,000 Bengali women and girls were raped by the Pakistani army. As I outlined in Chapter 1, both the physical and the socialsymbolic element of genocide were present in this example. Furthermore, reproductive violence was enacted by the State through its regulation of the post-war reproductive body. 
3. Gender essentialism - that is, the equation of maleness with war-fighting and femaleness with victimisation - obscures the experiences of male victims and female perpetrators (Chapters 5 and 6).

In the Introduction, I asked the following: on what basis do we make the claim that women are disproportionately affected by war/armed conflict? Does the assumption that women are disproportionately impacted diminish how we view male suffering? How do we interpret male civilian victimisation? For my part, I believe that gender essentialism underpins the arguments laid out in the disproportionality thesis. That is, if one believes that men and boys are always and already combatants - and by extension, the perpetrators of the violence(s) of war/armed conflict - on a rudimentary level, it makes sense to view female civilians as disproportionately impacted by war/armed conflict. Therefore, it seems to me, that part of the project of redirecting our attention away from this focus on disproportionality requires that we contest the gender essentialism that underpins its logic (I will return to this shortly in the section below: 'Rethinking gender and the violence(s) of war/armed conflict').

The fifth chapter of this book focused on female perpetrators in Iraq. However, this is only one example of women's more active role in war/armed conflict. While the fighters of old and new wars are predominantly male, women have also participated in war/armed conflict either, indirectly through numerous auxiliary roles or, directly through combat roles. The Soviet Union, for example, recruited women into their army units during the First and Second World Wars, as well as the Russian Civil War (Pennington, 2010). Women in the UK and oversees served as auxiliaries in non-combat roles during the Second World. This included the 'War in the Auxiliary Territorial Service (ATS),' the 'Women's Auxiliary Air Force (WAAF)' and the 'Women's Royal Naval Service (WRNS)' (Mason, 2018). Examples of females' active participation include but are not limited to: female fighters in the Congo, Uganda, Sierra Leone (Turshen, 2016), Kurdish fighters in Syria; women in the Farabundo Martí National Liberation Front - a guerrilla movement in El Salvador (Ramos, López, \& Quinteros, 2015); and female fighters of the Liberation Tigers of Tamil Eelam in Sri Lanka. This list is by no means exhaustive but should provide readers with an idea of the range and scope of women and girls' relationship to war/armed conflict. Allied to my focus on female perpetrators of the violence(s) of war/armed conflict, Chapter 6 examined the experiences of male victims. Both chapters defy gender essentialism and underscore the reductive nature of the disproportionality thesis.

\section{Climate variability intersects with gender to inform structural and inter- personal forms of violence within and beyond the conflict zone (Chapters 4 and 6).}

In Chapters 4 and 6 - drawing on the conflicts in Syria and Darfur, respectively I considered climate variability and its relationship to conflict. This broadens our analytical framework and adds depth and complexity to our understanding of both the causes and consequences of modern conflicts. These chapters outline 
how macro-level environmental factors coalesce with meso-level policies and practices (such as neoliberalism in the case of Syria and Arabisation in Darfur) to shape interpersonal and structural forms of violence. I explored these intersecting phenomena through a gendered lens. This adds further depth and value to the discussion. As demonstrated, in Syria and Darfur, extreme droughts, caused by climate variability, led to increases in poverty (in the former) and clashes over natural resources (in the latter). For women and girls, this implicated them in new war illicit economies. For Darfuri African males, this placed them at risk of genocidal and reproductive violence.

\section{The violence(s) of war/armed conflict take place at the interrelated macro- meso- and micro-levels (all chapters).}

In every chapter of the book, and in every case study I have reviewed, the particular form of violence under review has been explored at the macro- mesoand micro-levels. At the macro-level, I connected global economic geopolitical policies and practices, as well as environmental forces, with the interpersonal and structural GBV(s) taking place within and beyond conflict zones. In order to explore these through a gendered lens, I drew upon globalisation masculinities, specifically masculinities of postcolonialism and neoliberalism.

At the meso-level, I examined how gendered cultural practices, the gender hierarchy, as well as ethnic identity/identities, are reproduced in institutions and State-led agendas which in turn inform the violence(s) that take place during war/ armed conflict. In the case of the DRC, militarised masculinity, pre-existing gender inequalities and Congolese rape laws were reviewed. The violence(s) that took place at Abu Ghraib, as part of the invasion and occupation of Iraq, can be linked to the US military institution. In the case of Syria, I demonstrated how denial of girls' education is connected to patriarchal beliefs about gender roles and gendered divisions of labour. In relation to Darfur, I explored the institutionalisation of local Arab Sudanese masculinities, which led to genocidal and reproductive violence against African Darfuri men.

Finally, at the micro level, I narrowed the focus to individual acts of violence. While agency can be ascribed to these actors, their actions are informed by the aforementioned macro- and meso-level policies, practices and drivers. In Chapters 2, 3 and 4, the feminist political economy approach was used to facilitate this three-level interrelated analysis. Across all examples, I have highlighted how these three interconnected levels interact to both produce and reproduce structural, institutional, interpersonal and State GBV(s) during war/armed conflict.

\section{Rethinking Gender and the Violence(s) of War/armed Conflict}

Having reviewed the five key messages of the book, in the next section, I will interrogate what it really means when one argues that it is more dangerous to be a woman than a soldier in armed conflict. 


\section{Gender and the Violence( $s$ ) of War and Armed Conflict}

As a thought experiment let us, for now, accept Major General Patrick Cammaert's statement ('it is perhaps more dangerous to be a woman than a soldier in armed conflict') as accurate. In doing so, what are the conceptual and empirical grounds to support this claim? As we saw in our discussion of the Holocaust and the 1971 Liberation War in Bangladesh, as reproducers of the nation, women and girls were targeted for rape and sexualised genocidal violence. Within the political economy of new wars - where State-corporate crimes are committed and the illicit economy flourishes - women and girls become disposable commodities. As we saw in the DRC, the use of rape and sexual violence against women and girls is strategic: it is used to terrorise and displace the local population to ensure that combatants on the ground, as well as transnational organisations, have access to the minerals that end up on the global market. In this instance, females are expendable. In Iraq and Syria, females are used as commodities by profit-seeking networks who exploit the illicit economy within and beyond the conflict zone. Here, women and girls are trafficked and sold into sexual slavery. In addition to these acts of interpersonal violence, women and girls are at risk of structural violence within the political economy of new wars. As we saw, neoliberal policies, increases in poverty and a lack of employment opportunities (exacerbated by the drought in the case of Syria) forced women to engage in coerced sexual activities during these conflicts. Taken at face value, one could argue that this is evidence that it is more dangerous to be a woman than a soldier in armed conflict. However, I believe there is a more fruitful way of thinking about all of this. This requires (on a conceptual level) that we dissect the relationship between gender and war/armed conflict.

Here is the conundrum as I see it: the notion that it is more dangerous to be a woman than a soldier in war/armed conflict comes from the woman-as-nation thesis. To reiterate, within this line of thinking, females and their reproductive bodies are regarded as the vessels through which national, racial, ethnic and religious identities are reproduced. They are viewed as both symbolically and corporeally mothers of the nation. This equation is discursively constructed. To assist us in unpacking this, we need to return to our discussion of semiotics and the cultural meaning of signs (see Chapter 5). As noted earlier, signs comprise the signifier, the physical form. They also contain the signified, the concept (Huntington, 2013). My suggestion is this: the female body (the sign), through its biological reproductive function (the signifier) acts as a reproducer of the nation to which she belongs. This leads to the woman-as-nation thesis (the signified). For me then, the 'danger' lies in the semiotics of language; in gender essentialism - and by extension, the hierarchical gender binary system (more on this below). For example, if we consider gendered justificatory narratives (discussed in Chapters 3 and 5 in relation to the invasion and occupation of Iraq), these are based upon ontological constructions of women as weak, fragile beings who are in need of protection. The corollary of this is that men are strong and are required to fight on behalf of these 'beautiful souls' (see Elshtain, 1982; Lobasz, 2008; Sjoberg, 2007; Sjoberg \& Peet, 2011). However, as we saw in Iraq, intervention and occupation does little to diminish GBV against women and girls. In fact, not only does it exacerbate existing types of GBV, it can lead to new types of violence, for example structural GBV(s). 
Two further problems arise from this reductive framing of women and men vis-à-vis war/armed conflict: (1) the securitisation agenda which focuses on women and girls at the expense of men and boys and (2) the persistent view of female perpetrators as aberrant. Moving forward my proposal is that we take on board the work of Krylova (2016, p. 309) who seeks to understand gender outside normative and binary-bound contexts.

In her article, Gender Binary and the Limits of Poststructuralist Method, Krylova (2016, p. 309) proposes that we '...broaden our theoretical framework...to revisit the concept of dichotomy and differentiate it from binary connotations of difference'. Before we get to this distinction, we will begin with her interpretation of the concept of 'gender binary'. For Krylova (2016, p. 307), this is a:

[C]oncept [that] carries a rich repertoire of connotations, which informs and influences the gender category: those of radical distinction, opposition, mutually exclusive and exhaustive differentiation, hierarchy, domination, oppression - in all their myriad historical forms.

Based on her research into female combatants during the Soviet era, specifically the memoir of Zoia Medvedeva, Krylova (2016) encourages us to move beyond the concept of gender binary towards the idea of a 'nonbinary dichotomy'. Let us explore this in more detail. Zoia was the commander of a male machine-gun platoon in 1941 in Soviet Russia (Krylova, 2016, p. 317). As a Soviet female soldier her story is not unique. Soviet women volunteered as combatants during the Second World War (Krylova, 2016). They also, following authorisation by Stalin, established an all-female team of night bombers. Referred to as 'The night Witches', ${ }^{1}$ this '588th Night Bomber Regiment...became one of the most remarkable fighting forces of World War II'. Referring specifically to the story of Zoia, while gender forms a part of this landscape, Krylova (2016, p. 317) argues that 'it did not operate as an omnipresent binary enterprise'. Furthermore, Zoia's accounts do not describe female soldiers as feeling as though they were entering into 'a male space' (Krylova, 2016).

Here, it is worth quoting Krylova (2016, pp. 317-318) at length:

[...] 'women-soldiers'.... are not described by Zoia as a self-evident contradiction assembled out of binary parts...that is, as 'masculine women', enacting or mimicking male behaviour. Far from it, the social identity of a 'women-soldier' constitutes what the Soviet society referred to as a 'different concept of a woman'

\footnotetext{
${ }^{1}$ The Night Witches often flew their planes at night. As they approached their targets, they would idle their planes before releasing their bombs. This tactic meant that their planes made whooshing noises as they glided by. It is reported that, for their German victims, this noise was reminiscent of a witch's broomstick, hence the name 'Night Witches' (see Garber, 2013; Grundhauser, 2015).
} 
whose feminine qualities were not seen as necessarily compromised. Rather, they were informed with new connotations of the feminine. For example...I read the presence of red poppies at her gun site (marking one's combat space with flowers was a common preoccupation among women-soldiers) not as an importation of conventional femininity into the male trenches but as women combatants' attempt to change the very meaning of the feminine, to detach femininity from its binary associations with weakness and debilitating frivolity and to visually change the gender map of combat spaces.

Based on this, Krylova believes that the term dichotomy - which does not assign negative or positive values to its parts - can assist us in moving beyond binary understandings of gender. Within this framework, we explore how differences between the genders are produced, but we also acknowledge that '...not all dichotomies must be necessarily binary' (Krylova, 2016, p. 320 emphasis in the original). In other words, dichotomies, unlike binaries, do not assign a positive or negative value to males/masculinity/ies and females/femininity/ies respectively. Rather, they acknowledge differences, but not in a hierarchical sense. While Krylova's proposal is drawn from a specific historical time period, the conceptual foundations of her theoretical framework need not be time or context bound. This leads me to ask: how might her 'nonbinary dichotomy' assist us in moving away from gender essentialism and the assumption that it is more dangerous to be a woman than a soldier in war/armed conflict?

First, it is important to note that I believe that the dismantling of gender essentialism - the assumption that certain behaviours are inherently male/female needs to work in conjunction with nonbinary dichotomies. So, while we can acknowledge that there are differences in the experiences of males and females, we must regard these as socially constructed normative ideas about gender and gender roles. These gendered expectations are internalised and performed by males and females who subscribed to these conventional ideals. This is stage one. Stage two involves applying the nonbinary dichotomy which removes the positive and negative connotations that map onto the categories male/female respectively.

Now that I have clarified this two-stage approach let us continue with our application of the nonbinary dichotomy. Here, I will draw out the various elements included in Krylova's definition of the 'gender binary' cited above.

\section{'Hierarchy, Domination, Oppression'}

In the Introduction, I talked about the bacha posh, the Afghan girls who dress like boys because being female is considered a 'humiliation' or a 'failure' in Afghan culture. Conversely, being male is considered a 'triumph' (Nordberg, 2014, p. 39 as cited in Banwell, 2015a, pp. 587-588). However, the benefits and privileges associated with being male are short-lived: the bacha posh cannot present as male beyond puberty as they will be required to marry in order to fulfil their childbearing responsibilities. Similarly, within the conflict zone in Syria, young 
girls who enter into marriage at a young age are forced to abandon their education so they can begin their childbearing and childrearing responsibilities. While this is used as a coping mechanism by fathers to alleviate poverty and secure their daughters' financial future, it also speaks to patriarchal beliefs about the role of females within the domestic/private sphere. This is a role where access to education is secondary. Here, we see how traditional gender binaries - which are hierarchical - associate males/masculinity/ies with freedom, privilege and power and females/femininity/ies with powerlessness, a lack of freedom and a lack of decision-making power. In cases of early and forced marriage, to paraphrase Krylova (2016), we need to detach conventional femininity from its binary associations with domesticity to ensure that young girls are not denied access to education, but also not placed at an increased risk of sexual violence and exploitation from their much older husbands. This will reduce the dangers they face.

\section{'Connotations Which Informs and Influences the Gender Category'}

As reproducers of the nation females are targeted during war/armed conflict. Here, the connotations associated with the maternal body - as symbolic and corporeal mothers of the nation - means that women, as a gender category, are attacked. In this example, we need to revise the meaning of the feminine and detach it from its essentialist association with biological motherhood. Again, this will reduce the dangers women face during war/armed conflict.

\section{'Radical Distinction, Opposition'}

As noted at the outset, differentiated gender roles are performed and reproduced within the military institution. As we saw in the DRC, militarised masculinity expects men and boys to be tough and aggressive. Furthermore, they are required to perform a violent heterosexual hegemonic masculinity. In opposition, idealised militarised femininity requires females to engage in sanitised fighting (Sjoberg \& Gentry, 2007).

Within my framing of 'war-on-terror femininity', as outlined in detail in Chapter 5 , the female soldier is violent and aggressive. She can engage in cruelty and torture. And while I based this alternative militarised femininity on the war on terror, its subversion of binary associations of femininity with weakness, frailty and vulnerability can be applied more universally. This means acknowledging that females, like males, can and are violent and aggressive, thus challenging the equation of femaleness (and conventional femininity) with passivity and non-violence.

\section{Mutually Exclusive and Exhaustive Differentiation}

Within the gender hierarchy, femininities are always positioned below masculinities. To paraphrase Connell and Messerchmidt (2005), masculinity is defined in contradistinction to femininity. Put another way, the feminine is always inferior to the masculine. However, my 'war-on-terror femininity' and the images I reviewed in Chapter 5, challenge this. Now I want us to consider the implications of the gender hierarchy for male victimisation. 
As demonstrated in Chapter 5, the three women involved in the sexualised violence and torture at Abu Ghraib were used to feminise and emasculate the enemy. Rape and reproductive (genocidal) violence against males, disempowers men on an individual level, but it can also emasculate the group to which he belongs, thereby sending a message of symbolic elimination/destruction to the group as a whole (Ferrales, Brehm, \& McElrath, 2016; Sivakumaran, 2007, p.274). Going back to Krylova's reading of Zoia's memoir, if we detach femininity from this binary association with weakness and inferiority, the power of rape and reproductive violence to emasculate and feminise the enemy is diminished.

In all of these examples, '[changing] the very meaning of the feminine' (Krylova, 2016, p. 318) - that is, applying the nonbinary dichotomy - assists us in challenging reductive understandings of the roles and experiences of males and females during war/armed conflict. Critics might argue that this is a purely academic exercise, that tackling this from a conceptual standpoint will do little to address the lived experiences of those affected by the violence(s) of war/armed conflict. And yet, as we have seen throughout this book, gender essentialism and binary constructions are pervasive and have informed (national and international) discourses (i.e. the securitisation agenda), cultural practices, foreign policy agendas (justifications for invading Iraq) and the tactics of war/armed conflict (woman-as-nation, man-as-protector). Ultimately, these discursive constructions have served to reinforce the notion that it is more dangerous to be a woman than a soldier in war/armed conflict. That said, I will now consider some of the practical steps we need to take to address the GBV(s) of war/armed conflict. These are demarcated along empirical, policy, legal, institutional and cultural lines.

\section{Research (Empirical)}

As I noted earlier, despite an increase in research on the links between climate change, and violent conflict, no direct causal relationship can be found (De Juan, 2015; Detges, 2017; Schilling, Saulich, \& Engwicht, 2018; Von Uexkull, 2014; Work, 2018). Rather, environmental changes, leading to extreme weather events intersect with pre-existing grievances that can lead to conflict (Von Uexkull, 2014; see also Detges, 2017; Schilling et al., 2018). Drawing on the conflicts in Syria and Darfur, I examined gender, climate variability and conflict. Additional robust qualitative and quantitative data are needed to measure the relationship between conflict, extreme weather events (caused by climate variability) and interpersonal and structural GBV(s) that occur as a result.

Writing in 2016, Ferrales et al. (2016, pp. 567-568) argued that 'research on gender-based violence against men is in its infancy and has faced several limitations, including a disproportionate focus on the former Yugoslavia'. Indeed, to my knowledge, since then there have only been a handful of articles published that address this subject (these are reviewed in Chapter 6). In fact, while researching my chapter on men and boys, I was struck by the paucity of scholarly articles on the topic of conflict-related sexual violence (CRSV) against men and boys, particularly when compared with the copious amounts of material about female victims/ survivors. SGBV against men and boys, has been listed in over 25 conflicts over 
the past 30 years, yet this is not reflected in the amount of literature we have on this subject. To redress this, research with male survivors/victims is needed. This empirical work must address the causes, the nature and the range of violence(s) to which men and boys are subjected to. As with females, this work must extend beyond rape and sexual violence. For example, Aijazi and Baines (2017, p. 464) conducted research with demobilised men from the Lord's Resistance Army in Uganda relating to their experiences of forced marriage. As they note: ' $[t]$ he majority of scholarship on forced marriage focuses on women's experiences of harm'.

\section{Securitisation (Policy)}

As noted previously, the securitisation agenda identifies women and girls as those most at risk of rape and sexual violence. This message is reproduced in numerous policy documents, most notably in a number of UN Security Council Resolutions (UNSCRs). Up until 2013, before UNSCR 2106 was passed, men and boys had not been included within these policy documents. Going forward, we need to ensure that the language of these documents (and others that address CRSV) includes the experiences of men and boys (see, for example, the 2019 annual report by the UN Secretary General on CRSV).

\section{National and International Laws}

\section{The ICC and Forced Pregnancy}

To reiterate, the Statute of the International Criminal Court (ICC) defines forced pregnancy as: 'the unlawful confinement of a woman forcibly made pregnant, with the intent of affecting the ethnic composition of any population or carrying out other grave violations of international law' (Rome Statue of the Criminal Court, 2011, p. 4). Taking a different position, The Holy See suggests that the Statute need only 'criminalize the act of forcibly making a woman pregnant, but not the subsequent conduct of forcibly keeping her pregnant' (Grey, 2017, p. 920, emphasis in the original). They proposed the term forcible impregnation rather than forced pregnancy. However, forcible impregnation was not considered as an acceptable replacement for forced pregnancy. This is because the former only refers to forcibly making a woman pregnant, whilst the latter involves keeping the woman pregnant. Thus, this definition 'excludes situations where the victim becomes pregnant by force, but is not subsequently confined' (Grey, 2017, p. 921).

In line with Grey's (2017) notion of reproductive violence, I believe that forcible impregnation should be listed as a crime by the ICC; one that is distinct from forced pregnancy as an act of genocide. This would recognise the experiences of women who have been forcibly impregnated, denied access to a safe abortion and then forced to continue with an unwanted pregnancy (as discussed in relation to Syria). Removing the requirement that women be confined would also mean that the experiences of women and girls, such as those who were raped and impregnated during the 1971 Liberation War, would be recognised and perpetrators criminalised under international law. 


\section{Rape, Honour Killings and Trafficking Laws in the DRC, Iraq and Beyond}

States that are party to international laws prohibiting rape and CRSV should incorporate these into their national laws (as argued with reference to the DRC). Corruption within the local Criminal Justice System as well as the high fees associated with prosecution (including travel costs) need to be addressed. If we can improve the system itself, including how evidence is gathered, this may incentivise victims to come forward and report their experiences. As noted in previous chapters, one of the main reasons why survivors (both male and female) remain silent is due to fear of being stigmatised by their family and/or community. As we saw in Iraq, in some cases this led to honour killings in order to remove shame and restore family honour.

While removing the internalised shame victims/survivors may feel is arguably an impossible task, this should not deter us from tackling the shortcomings of the judicial process from a practical and logistical standpoint. Nor should we abandon efforts to criminalise and/or enforce existing laws relating to honour killings. Relatedly, anti-trafficking laws need to be enforced and perpetrators prosecuted. Women and girls who have been trafficked for sexual purposes are victims and should not be criminalised, as was the case in Iraq.

In terms of men and boys, laws that criminalise homosexuality need to be revoked, thereby making it easier for male victims to come forward. Acts of reproductive violence in the form of genital harm need to be fully acknowledged and not categorised as lesser crimes when dealt with by the ICC or other courts (Grey \& Shepherd, 2012).

\section{The Military (Institutional)}

As noted with reference to the DRC, the performance of heterosexual hegemonic masculinity is reinforced within the military. This is an institution that normalises rape and sexual violence. It allows individual men to subvert their marginalised position within the hierarchy of the military and society more generally. Research by Trenholm, Olsson, Blomqvis, \& Ahlberg (2013, p. 212) with 12 child soldiers from a range of rebel and official State military groups in the $\mathrm{DRC}$, revealed that 'starvation, the use of mind-altering substances, forced marches and sleep deprivation' were among the measures used to ensure compliance from these child soldiers. This included engaging in gang rape. Most of the boys had either been abducted or forced into the military, with some joining to alleviate lives of abject poverty. The boys recount atmospheres of subjugation within the military, designed to maintain their obedience and loyalty to authority. This was often achieved through violence, including being beaten with sticks. Their involvement in acts of sexual violence signified their commitment and conformity to the aggressive heterosexual code of the military. As I argued earlier, this culture of militarised heterosexual masculinity, that condones violence against women and girls, needs to be challenged. However, in cases of forced recruitment, where male child soldiers are forced to rape, the ICC (and international law more generally) needs to recognise and prosecute commanders who order these acts of violence. 
Despite the involvement of female soldiers in sexualised violence and torture at Abu Ghraib, female violence is not embedded within the institutional code of the military. This was underscored by the need for my recuperative narrative in the form of war-on-terror femininity.

\section{Pre-existing Gender Inequalities and Discrimination (Cultural)}

As I argued in the Introduction, pre-existing gender discrimination and gendered inequalities are reproduced and exacerbated during war/armed conflict. These need to be tackled prior to, during and in the aftermath of war/armed conflict. Laws, programmes and policies that promote equality between males and females need to be upheld and/or developed. Restrictions on women's freedom of movement need to be removed. Denying females access to reproductive healthcare and/ or education should be regarded and punished as acts of structural violence.

So, to finish where we began: is it more dangerous to be a woman than a soldier in armed conflict?

In the six chapters of this book my qualitative analysis of the unique lived experiences of men, women, boys and girls eschews misguided tendencies to pursue quantitative, comparative analyses to prove the disproportionality thesis. The experiences of victims, survivors and perpetrators (boys, men, women and girls) were unpacked through a gendered lens. By unpacking ontological constructions of females as weak, passive and in need of protection and, conversely, of males as always and already actors and perpetrators, I have offered a counter narrative to the reductive gender essentialism inherent in many accounts of war/armed conflict. This alternative story about gender and the violence(s) of war/armed acknowledges that males and females experience such violence in unique and gendered ways; but does not seek to quantify the material reality of those affected by war/armed conflict. Non-essentialist and nonbinary dichotomous depictions of the categories male and female are key to fully understanding those who victimise and those who are victimised during war/armed conflict.

If the female body, and its biological reproductive function, continues to stand in for the nation, and if men and boys continue (and indeed are expected) to act as fighters and protectors, gendered notions of who 'is dangerous' and who is 'in danger' during war/armed conflict will remain unchallenged. 